\title{
Did Jahili Arabs really despised Crafts and Craftsmen
}

\author{
Ahmad Ghabin, Al-Qasemi Academy, Baqa al-Gharbiyya, Israel
}

\begin{abstract}
From the late Roman period the Saracens (the people of Arabia) were described by the Roman historian Ammianus Marcellinus (380 CE.) as wandering over extensive lands, having no home and no fixed abode. In such lifestyle, they abstained of works and handicrafts that obligate their executors to be settled.

Such being the case, it would be important to ascertain the real attitude of the Arabs towards arts and crafts and, more importantly, to understand its original compelling reasons. One possible way to do this is to make a distinction between the views of the townsfolk and those of the Bedouin in Arabia. It is also necessary to study this issue within the historical and cultural milieu of the ancient Near East. Special emphasis should also be given to the links of the pre-Islamic Arabs with neighboring cultures such as those of the Mesopotamians, the Palestinian and Babylonian Jews and the Hellenists. The whole issue is of special importance in the study of the economic, social and artistic history of Islam. Here, one should ask questions like: Was there any continuation of the pre-Islamic attitudes within the Islamic milieu? If the answer is yes, what impacts did these attitudes have on Islamic society, economy and art?
\end{abstract}

Keywords: Jahili Arabs, nomads, handicrafts, Jahili poetry, blacksmithing, artisans, Islamic art.

\section{INTRODUCTION}

$\mathrm{D}$ iodorus Siculus (60-30 B.C.), referring to the Arabs who inhabited the eastern parts between Syria and Egypt, described them as:

"Being difficult to overcome in war they always remain unenslaved; in addition, they never at any time accept a man of another country as their overlord and continue to maintain their liberty unimpaired."

In consequence, no king was ever able to enslave this nation. ${ }^{1}$

As for their customs, he said (19.94):

"They live in the open air, claiming as native land a wilderness that has neither rivers nor abundant springs that could enable a hostile army to obtain water. It is their custom neither to plant grain and set out fruit-bearing trees and use wine nor to construct any permanent abode; and if any man is found acting contrary to this, his penalty is death".

\footnotetext{
${ }^{1}$ Diodorus History, 2.1 .
}

More interestingly another Roman Historian Ammianus

Marcellinus (c. 380 CE.) described the Arabs as follow:

"nor does any member of their tribe ever take plow in hand or cultivate a tree, or seek food by the tillage of the land; but they are perpetually wandering over various and extensive districts, having no home, no fixed abode or laws; nor can they endure to remain long in the same climate, no one district or country pleasing them for a continuance." 2

A more decisive statement came from Eusebius 'father of church history' (d. $339 \mathrm{CE}$ ), who considered the Arabs within the nomadic people among whom one will never find a banker, modeller, painter, architect, geometer, singing-master and actor of dramatic poems. ${ }^{3}$

\section{PRE-ISLAMIC ARABS}

Relying on such information, Goldziher, in a short article, concluded a long time ago that the Arab Bedouin society despised most of the handicrafts and that mostly foreigners or people of low status were engaged in them in Arabia. ${ }^{4}$

In fact, engaging in handicrafts by free people of low status, slaves and foreigners is well known in other and older cultures. In the ancient Jewish sources, in general, there is an ambivalent attitude towards the occupation of handicrafts. The expressions of 'defective craft' and 'excellent craft' were common in the tongue of Ancient Jewish scholars. Accordingly, occupations such as the arts and crafts of perfumery and of the goldsmith were favored while tanning, pottery making, weaving, blacksmithing and dyeing were despised crafts. ${ }^{5}$

In the late $6^{\text {th }}$ and $5^{\text {th }} \mathrm{c}$. BC a positive attitude towards artisans took place in Greece. On the one hand, they were highly appreciation in Corinth and in Athens, yet many of them could not enjoy full citizen rights as their slave or metic (foreigner) status would not permit it. On the other hand, Plato, Aristotle and others had a high estimation of the products of the artisans but a very low one of their producers. For example, Aristotle stated: "The good man and the statesman and the good citizen ought not to learn the crafts of inferiors except for their own occasional use; if they habitually practice them, there will cease to be a distinction between

\footnotetext{
${ }^{2}$ Ammianus Marcellinus, the Roman history, XIV, 3, 4, p. 11.

${ }^{3}$ Eusebius of Caesarea, 6.10

${ }^{4}$ Goldziher, “Die Handwerke,” pp. 316-318.

${ }^{5}$ See Ayali, Poalim vi-Ummanim, pp. 79-83, 97-100.
} 
master and slave." ${ }^{6}$ Similarly, the Roman Cicero, Seneca and others relegated the craftsman to a less than human level or to the rank of a second-class citizen. ${ }^{7}$

Back to the people of Arabia, especially those of north Arabia. They were better known as groups of nomad tribes living in tents, moving over wide expanses, behaving anarchically, invading settled lands, abstaining totally from cultivating trees or planting grains for their living. They thus practiced their freedom and rejected any kind of submission to foreign ruler. They nevertheless bred camels and used them successfully in their inroads but also in their scent trade with the settled world. ${ }^{8}$ In our own interest, it is important to understand their hatred of farming work. Doing such work means to lead a sedentary lifestyle, to waive the love for freedom to rove freely in the expanses of the desert. Here, I believe, lies hidden one of the reasons for the scorn shown by nomads for sedentary people, some remnants of which still exist in our time. I mean the mutual scorn between those of Bedouin origin and the townsfolk in the Middle East. ${ }^{9}$ For the Bedouin, living in a town means to be involved in its everyday life, to accept its laws, to be under the authority of its ruler, to live in it permanently and, more importantly as regards our own interest, to be engaged in different occupations and crafts for a living and in doing so to serve others. However, the existence of this attitude of contempt did not mean that crafts and artisans were absent in the milieu of the Bedouin Arabs. Evidences from the various written and archaeological sources prove that the 'Bedouin settler'Arabs were exposed to the surrounding civilizations of the Ancient Near East, Greece and Rome as well as that of the Persians. Furthermore, Archaeological excavations and inscribed texts in diverse places in Arabia proved the existence of a variety of crafts and general occupations from the end of the third millennium and continued until the advent of Islam. ${ }^{10}$

Hoyland presented a very interesting theory about the nature of relationship between nomadic and sedentary Arabs. He suggested that between the two sides existed a kind of complementary economic relationship that brought both sides to "share certain techniques, beliefs, and kinship organizations".

${ }^{6}$ Plato, The Dialogues, vol. 3, 415a-c, p. 104; Aristotle, Politics, 1278a2-12, p. 108. See also Tanaway, "Arts and Crafts in Plato and Collingwood," vol. 50, No. 1 (winter, 1992), pp. 45-54; Hasaki Companion, vol. 1, pp. 255-272; the Cambridge Companion, pp. 154-155.

${ }^{7}$ Morel, "The Craftsman" p. 214-244.

${ }^{8}$ Herodotus (484-425 BC) was the first Greek historian to draw the attention to the particular role of the Arabs in this trade; see Herodotus, History, Thalia, 107-108, pp. 243-244. According to him, Arabia was the only region that grew frankincense, myrrh, cassia, cinnamon and labdanum. See also the detailed reference of Diodorus, History, 2.49, to the importance of the aromatic and frankincense trade for the people of Arabia Felix and for the inhabited world of the Ancient Greeks and Romans. Also Strabo (64 B.C.-21 A.D.), Geography, 1.2.32, described the wealth acquired by Arabia from producing and exporting aromatics to the Roman world. See also the recent research of Mclughlin, Rome and the Distant East, pp. 61$81,141-178$.

${ }^{9}$ It is needless to say that still in our time the Bedouin use the title 'fallah' (farmer) as an 'insult' to the townsfolk while the townsfolk answer the Bedouin with the opposite 'insult' 'badawi'.

${ }^{10}$ Hoyland, Arabia, p. $77-78$.
Historically, it seems that Ibn Khaldun was the first scholar to indicate the negative attitude of the Arabs towards handicrafts in his Muqaddima. He titled Section 20 of Chapter 5 "The Arabs, of all people, are least familiar with crafts". He explained this view saying:

"The reason for this is that the Arabs are more firmly rooted in desert life and more remote from sedentary civilization, the crafts, and the other things which sedentary civilization calls for, (more than anybody else)... Therefore, we find that the homelands of the Arabs and the places they took possession of in Islam had few crafts altogether, so that (crafts) had to be imported from other regions.

\section{THE DESPISED CRAFTS}

The craft of blacksmithing was one of the most despised handicrafts and it extensively served the poets in their defamatory poetry. The poet of the Prophet, Hassan $b$. Thabit, derogated some blacksmith saying: You, people of blacksmiths! Are you proud of your blacksmiths' bellows, do not you see that your father built his bellows before he built his house! Just dissolve the ash of your bellows and you will discover that you are ignoble. ${ }^{11}$ The same Íassan was defamed by another poet for being a son of a Yemenite smith who worked blowing the fire in his bellows. ${ }^{12}$ Perhaps the poet here intended to defame him as being of Yemenite origin for whom blacksmithing was a familiar occupation. Another poet slandered someone saying that there is nothing to expect from him; after all, he came from a people of smiths! $!^{13}$ The poet Amr bin Kulthum directed a similar defamation towards the family of the king of al-Hira al-Numan bin al-Mundhir saying "what could his mother hope for from the dwellers of alKhawarnaq (his palace); they are all smiths and weavers, or what good can we get from a man whose uncle blows the kir (the blacksmith's goatskin bellows used for blowing) and shaping earrings and nose-rings in Yathrib". ${ }^{14}$

The name qayn could bear different meanings: blacksmith, goldsmith and even slave-girl singer. It seems that this equalization originated from the fact that in both smithing crafts almost the same tools were used, the kir (bellows), the kur (melting pot) and the blazing fire, and in all of them exists the aspect of giving service (khidma) to others. The Arabs, mainly the Bedouin, adopted the same scornful view towards all kinds of handicrafts such as tanning, weaving, spinning, tailoring and tilling.

An Umayyad official in Syria was ordered by the Calif alWalid to classify the craftsmen as follows: the spinner and the shoemaker, the cupper and the veterinarian, the cloth dealer and the money changer, the teacher and the eunuch, the slave dealer and the Satan, every pair in the same rank. ${ }^{15}$ Furthermore, in the different attitudes towards craftsmen in Islamic sources we find that the most despised were spinners, weavers, tanners, cuppers, smiths and sweepers, apparently

\footnotetext{
${ }^{11}$ Íassan, Diwan, pp. 63-64; al-Barquqi, Sharî Diwan Íassan, pp. 201-202.

${ }^{12}$ Yaqut, Mujam al-Buldan, Art. y-m-n.

${ }^{13}$ Qays b. al-KhaÔim, Diwan, p. 148.

${ }_{14}$ Amr b. Kulthum, DĐwÁn, p. 25, 30; Aghani, vol. 11, p. 61.

15 al-Raghib al-Asfahani, Mohadarat, vol. 1, p. 459.
} 
because they all shared a low income and hard, dirty working conditions. ${ }^{16}$

In spite of all this, when talking about the attitudes of the pre-Islamic Arabs towards crafts one must distinguish between those of the tribesmen and those of the townsfolk. Accordingly, the Arabic sources of Jahiliyya informed us that even the permanent people of Quraysh were engaged not only in trade businesses but also in different handicrafts such as tanning, blacksmithing and tailoring as well as butchery and carpentry. Under the title the occupations of the nobles, Ibn Qutayba recorded a long list of the crafts and occupations of pre-Islamic Meccan and other Arab nobles. ${ }^{17}$

As for the information about the occupations of the Jahili Arabs it is clear that many of the people of Mecca and of Yathrib (Medina) as residents of urbanized towns felt no shame in being engaged in crafts including the 'most despised' ones. According to Ibn al-Kalbi there was the blacksmith, the tanner, the butcher, the blood letter, the hairdresser, the dyer, shoemaker, seller of wine (khammar) and seller of dried dates (tammar). If there was any shame in practicing these crafts, it was more in the eyes of the nomad Bedouin, an attitude that continued in Islam and extended among the Arabs in general when they became masters of the new empire. At any rate, the existence of this large variety of crafts and occupations among the Jahili Meccan Arabs is a good indication of the positive attitude of the townsfolk towards all kinds of crafts.

Relying on the poetical sources it is likely that the Bedouins were those who despised and refrained from all kinds of handicrafts that might put an end to their free mobility. Anyway, it is also possible that the poor hygienic conditions such as bad smells, dirty water and materials and physical fatigue distanced certain people such as high-class townsfolk as well as the Bedouin from these occupations.

\section{CONCLUSIONS}

In the light of the aforementioned information we can sum up with several points concerning the artistic legacy of the Jahili Arabs. Creswell, the well-known scholar of early Islamic architecture, had initially stated that the pre-Islamic Arabs brought nothing architectural to the conquered countries and that the very few settled people of Arabia lived in hovels while the Bedouin suffered from "congenital claustrophobia" and Arabia constituted "an almost perfect architectural vacuum." 18 In his evaluation of the pre-Islamic heritage, Ettinghausen made no distinction between both societies. For him, it was about a primitive society that imported its "finer material of things" and even borrowed the names of these things from foreign cultures. ${ }^{19} \mathrm{M}$. Aga-Oglu opposed this view. Life in the settled centers of Hijaz, especially that of Mecca, he argued, was "in marked contrast to that of the nomads," and the people

16 al-Raghib al-Asfahani, Mohadarat, vol. 1, pp. 459-465; al-Abi, Nathr alDurr, vol. 7, pp. 168-175.

17 See the list of permanent Qurashi personalities, everyone with his craft occupation in Ibn Qutayba, Kitab al-Maarif, pp. 575-576 and in Thaalibi, LaÔÁPf al-Maarif, pp. 77-78. Almost the same list is given in al-Jahiz, al-Mahasin wal-addad, p. 93; al-Bayhaqi, al-Mahasin, p. 98.

${ }^{18}$ Creswell, Early Muslim vol. 1, pp. 40-41.

${ }^{19}$ Ettinghausen, "The Character," pp. 251-253. of these centers were "familiar with the material culture of an urban standard." ${ }^{20}$ Depending on our aforementioned discussion of the Jahili mode of life, I tend more to accept the view of Aga-Oglu. No matter how developed was their international commercial activity, in principle the Meccans conducted their economic and cultural activities with foreign lands to such a level that its citizens "had lost all taste for fighting and were content to employ a hired militia ${ }^{21}$ which undoubtedly made them familiar with the wealth and material aspects of life. More opposition to the views of Creswell and Ettinghausen come from al-Faruqi. ${ }^{22}$

In spite of Baqum's proclaimed building of the Kaba, there are some indications that the Arabs in general had architectural tastes of their own. In the Arabic, lexicons and poetry there are enough architectural and other artisanal terms and features, which means that both settlers and Bedouin were well aware of forms of building, arts, crafts, materials, tools and even tastes. Ettinghausen could be correct in attributing many of these terms to foreign cultures but this does not mean that they were not part of their own culture. The fact that these terms were arabicized means that the Arabs were aware of and impressed by the foreign world of crafts, art and architecture that existed all around them and it is likely that they took advantage of it. In the other domains of arts and crafts, despite the so-called derogatory attitude, we saw that the people of Arabia were well-acquainted with different kinds of arts and crafts. In the cities of Hijaz, they had city life, commerce, "products and symbols of high civilization in considerable quantity and variety". ${ }^{23}$ All of them, settlers and Bedouin alike, acquired in their annual markets, such as Ukaz, indigenous and imported products of perfumes, textiles, jewelry, blacksmithing, weaponry, leather and the like. ${ }^{24}$

Understanding the artistic heritage of Jahili Arabs occurs largely through an appreciation of the impacts of that heritage on Islam. In doing so, one must discern between direct and indirect impacts that the Jahili culture made on the Islamic one. In her consideration of some aspects in Umayyad art, M. Rosen-Ayalon observed correctly: "Two other spheres of interest should be taken in consideration when studying the Umayyad period. The first one has not only been overlooked, but has literally been banned as nonexistent - the possible contribution to Islamic art of Arabian pre-Islamic elements in Arabia proper, and the degree of its contribution." ${ }^{, 25}$ In another study, she pointed out the advance in our knowledge about pre-Islamic art in Arabia in the last decades that could stimulate scholars to make reevaluation of that art and its influence on Islamic art. She concluded that the "portrayal of

\footnotetext{
${ }^{20}$ Aga-Oglu, "Remarks" pp. 178-179. Before him O'Leary, Arabia, pp. 184185 , pointed out that "it is very evident that Islam cannot be described correctly as evolved amongst the simple Arabs of the desert... a city such as Mecca must have been susceptible to outside influences in the preIslamic age."

21 O'Leary, Arabia, p.184.

22 al-Faruqi, "Misconception," pp. 29-49, see especially pp. 33-35, 39-41.

${ }^{23}$ Torrey the Jewish foundation, p. 29.

${ }^{24}$ Ibrahim, "Social and Economic," pp. 347, 349-350.

25 Rosen-Ayalon, "Further considerations," p. 97. In a more recent article, "From Jahiliyya to Islam" pp. 483-505, she pointed out the increasing knowledge about the pre-Islamic art in Arabia in recent decades, that could lead to re-consideration of the subject.
} 
certain female representations" in the entrance hall of the Umayyad palace of Khirbat al-Mafjar was undoubtedly an innovation that belonged to what she called the "Brave New World of the Umayyads." 26 She indicated correctly that the iconography of the female sculptured figures is close to literal expressions that exist in the literary sources of the Umayyads and continued into later Islamic sources. What interests us here is the new type of female stucco figures, which "are fleshy, somewhat plump and with full bosoms." Concerning this depiction, one should recall some desired characteristics of the woman's body as had been expressed and favored by Jahili and, later, by Muslim poets. Some poet described some beautiful girls as walking slowly and plumply because of their fat bodies. ${ }^{27}$ In al-Aghani there is an interesting description of a maidservant that the king of al-Hira sent as a gift to the Sassanian king Anushirwan. The maidservant had large head, with wide bosom, fat, has a wide waist, with fleshy thighs, her buttocks are fat and walking slowly with short strides. ${ }^{28}$ These characteristics continued to be much desired in the Islamic period. The prettiest girl is the one who has fleshy thighs, with heavy buttocks and big breasts. ${ }^{29}$ Thus, we see that in the imagination of the Arabs before and in Islam, the ideal woman was pictured as one whose body was stout and fleshy, with large head and bosom, heavy waist, heavy buttocks and fleshy thighs. Comparing this description with the female figures of Khirbat al-Mafjar that Rosen-Ayalon described as "fleshy, somewhat plump and with full bosoms," will show striking similarity, especially in the preference in both cases for women with heavy but balanced bodies. With this similarity, one may ask: is it not possible that simulations and imaginations that rose from the greatest of all Arab arts, poetry and prose, were a source of inspiration in the arts of the Muslim Arabs?

A. Badawi did a daring study on the contribution of the preIslamic Arabs to the Muslim art in 1964 in which he considered the legacies of both south-west Arabia and the rest of Arabia as sources of inspiration for Muslim art. ${ }^{30}$ Concerning south-west Arabia he notes that we are in fact dealing with a legacy profuse with eastern and classical GrecoRoman traditions that according to him found their way into Islamic monuments. For Example, he referred the Islamic Muqarnas to Mesopotamian traditions while the Kufic script and its monumental use he referred to south Arabian inscriptions. ${ }^{31}$ Concerning the contribution of people of barren Arabia, Badawi argued: "There must have been in existence other powerful factors, which through their impact on the indigenous cultures created an artistic movement characterized by a certain uniformity. These factors are to be sought in the intrinsic qualities of the Arabs as well as in their physical

${ }^{26}$ Rosen-Ayalon, "From Jahiliyya to Islam" pp. 483-505

${ }^{27}$ The poet is al-Marrar b. Munqidh al-Adawi, who lived in the Umayyad period. See al-Mufaddaliyat, p. 89

${ }^{28}$ Aghani, vol. 2, pp. 115-116. For more characteristics of Arab women see Ibn al-Sikit, Kanz al-Huffaz, pp. 314-331.

29 Jahiz, al-Mahasin wal-Addad, pp. 124, 130-131; idem, Rasal, vol. 2, p. 120. The same characteristics are repeated in the so-called erotic literature such as al-Qayrawani, Zahr al-Adab, vol. 2, p. 109; al-Tijani, Tuhfat al-Arus, pp. 338-343; Thalath Makhtutat, pp. 56-60.

${ }^{30}$ Badawi, "The Contribution," pp. 261-285.

${ }^{31}$ Badawi, "the Contribution," pp. 261-276. environment." Actually, he suggested considering the mode of life in nomad Arabia as a cultural heritage that indirectly inspired in the Muslim Arabs many characteristics of their art. Thus, the Bedouin ideal of freedom expressed in Arabic poetry and prose led to the denial of naturalism, to abstract conceptions in architectural settings and decorations and to their "horror vacui."32 Close to Badawi's view is Titus Burckhardt. Writing on the foundations of Islamic art, he suggested tracing some nomadic modes of life in several important characteristics of Islamic art. For example, He attributed the technique of the knotted rug, for example, to a nomadic origin in which geometrical forms are iterated. ${ }^{33}$

The conclusions of Badawi on the impacts of pre-Islamic heritage on Islamic art could be exaggerated, especially when he referred almost every characteristic of Islamic art to nonartistic practices of the Jahili Arabs. Nevertheless, speaking about the heritage of Jahili Arabia, three points should be remembered. First, it is agreed that there were two populations, the Bedouin in the barren deserts and the sedentary in the few cities of Hijaz. Of these cities, Mecca was the oldest and the largest religious and economic center in the region. It had the main features of urban society: a variety of religious, economic, social and semi-political institutions and offices, an aristocratic wealthy class (Quraysh), a low class of the weak, the strangers and the slaves, a system of alliances, local markets and cosmopolitan commerce. In other words, the Meccans were familiar enough with the material culture of an urban standard. ${ }^{34}$ Second, the Bedouin tribes held close commercial, social and religious relations with the sedentary population, mainly of Mecca. They took part in the local trade of Arabia and to some extent in the trade of the Meccans. The significance of this is that they also were not apart from the influences of the materialistic culture. The contents of their poetry and prose prove that they had some knowledge of the material culture that they received through their contacts with the sedentary centers. Third, one should remember that soon after the conquests the Muslim Arabs initiated imperial works of art - mosques and palaces - that reached the highest level in Islamic art. These works were designed to satisfy their new religious and secular needs, particularly in accordance with their special tastes. Undoubtedly, they adopted many alien architectural forms and elements but according to their own special selection and coordination. Consequently, we can likely trace in these works their own "spiritual complexion", which they derived from their Arabian environment. ${ }^{35}$ Burckhardt said: "The sense of rhythm, innate in nomadic peoples, and the genius for geometry: these are two poles which, transposed into the spiritual order, determine all Islamic art.",36

\footnotetext{
${ }^{32}$ Badawi, "the Contribution," pp. 276-278.

${ }^{33}$ Burckhardt, Sacred art, pp. 104-111.

34 Aga-Oglu, p. 179. On the economic and social conditions of pre-Islamic Mecca, see Ibrahim, "Social and Economic," pp. 244-358.

${ }^{35}$ Christie, "Islamic minor art," p. 108.

${ }^{36}$ Burckhardt, Sacred Art, p. 107.
} 


\section{BIBLIOGRAPHY}

[1] al-Abi, Mansur b. al-Husayn. (2004/1424). Nathr al-durr. Khalid Abd al-Ghani ed. Beirut: Dar al-Kutub al-Ilmiya,

[2] Aga-Oglu, M. (sept. 1954). "Remarks on the character of Islamic art." The Art Bulletin. https://doi.org/10.1080/00043079.1954.11408240

[3] al-Asfahani, Ali b. Al-Husayn Abu al-Faraj (1412/1992). Kitab alAghani, Samir Jabir ed. Beirut, Dar al-Kutub al-Ilmiyya.

[4] Ammianus Marcellinus(1894), the Roman history. Yonge, C. D. trans. London.

[5] Amr b. Kulthum, (1416/1996). Diwan. Emil B. Ya'qub ed. Beirut: Dar al-Kitab al-Lubnani.

[6] Aristotle. Politics. (1920) Jowett, B. trans. Oxford: the Clarendon press.

[7] al-A'sha, Maymun bin Qays. Diwan. al-RadwaniĐ, M. ed. Qatar: Wizarat al-Thaqafa wal-Funun, 2010.

[8] Ayali, Meir. (1987). Po'alim vi-Ummanim. Israel: Yad la-Talmud, [Hebrew].

[9] Babylonian Talmud, the Complete Soncino English Translation.

[10] Badawi, Alexander. (1964) "the Contribution of the Arabs to Islamic art." in Rivista degli Studi Orientali, 39, 261-285.

[11] Al-Baghdadi, Abd al-Qadir al-Baghdadi. (1418/1997). Khizanat alAdab wa-Lub Lubab Lisan al-Arab. Abd al-Salam Harun ed. Cairo.

[12] Al-Bakri, Abu Abdullah. (1417/1996). Mu'jam ma Istu'jim. MusÔafa al-Saqqa ed. Cairo.

[13] Al-Baladhuri, Ahmad b. Yahya. (1959). Ansab al-ashraf, Muhammad Hamidullah, Cairo: Dar al-Ma'arif.

[14] Al-Barquqi, Abd al-Rahman al- Barquqi. (1427/2006). Sharh Diwan Hassan bin Thabit. Beirut: Dar al-Kitab al-Arabi.

[15] Al-Bayhaqi, Ibrahim b. Muhammad. (1961). al-Mahasin walmasawi. Cairo: Dar al-Ma'arif.

[16] Burckhardt, Titus. (1967) .Sacred art in East and West: its principles and methods. Northbourne, L. Trans. London: Perennial Books.

[17] Cambridge Companion $=(2007)$. the Cambridge Companion to Plato's Republic. G. R. F. Ferrari ed. Cambridge: Cambridge University Press.

[18] Christi, A. H. (1931). "Islamic minor art and their influence upon European works." in Arnold, Th. ed. the Legacy of Islam. Oxford: Clarendon press.

[19] Creswell, K.A.C. (1932-1940) .Early Muslim Architecture. Oxford: Clarendon Press.

[20] Diodorus Sicilus. (1967).History. London: William Heinemann.

[21] Diwan al-Hudhaliyyin. (1995). Cairo: Dār al-Kutub al-Mișriyya.

[22] Goldziher, Ignace, (1894). "Die Handwerke bei den Arabern." Globus: Illustrierte Zeitschrift für Länder und Völkerkunde, Volume 66 pp. 203-205.

[23] Ettinghausen, R. (1944). "The Character of Islamic art." in Arab Heritage, Fares, N. ed. Princeton, pp. 251-267.

[24] Eusebius of Caesarea. (1903). Praeparatio evangelica. E. H. Gifford ed. 5 vols. Oxford: Clarendon.

[25] al-Faruqi, Isma'il R. (1970). "Misconceptions of the nature of Islamic art." Islam and Modern age, (1), 1, 20-49.

[26] Hasaki, E. (2012). A Companion to Greek Art, Smith, T. and Plantzos, D. eds. Wiley-Blackwell Publication,

[27] Hassan b. Thabit. (1281). Diwan. Tunis.

[28] Herodotus. (1901) History. Henry Cary trans. London.

[29] Hoyland, R. (2001). Arabia and the Arabs. London and New York: Routledge https://doi.org/10.4324/9780203455685

[30] Ibn Khaldun, Abd al-Rahman b. Muhammad. (1421/2001). Muqaddima. Shahada Khalil ed. Beirut: Dar al-Fikr. The English translation is after F. Rozenthal (the computerized version): https://asadullahali.files.wordpress.com/.../ibn_khaldunal_muqaddimah

[31] Ibn Qutayba, Abu Muhammad Abdallah b. Muslim. (1992). Kitab alMa'arif. Ukasha, Tharwat ed. Cairo: al-Hay'ati al-Misriyya al-Amma lil-Kitab.

[32] Ibn al-Sikit, Abu Yusuf Ya'qub. (1896-1898). Kanz al-Huffaz. Chikho, Louis ed. Imprimerie Catholique.

[33] Ibrahim, M. (Aug., 1982). "Social and Economic Conditions in PreIslamic Mecca." in International Journal of Middle East Studies, Vol. 14, No. 3, pp. 343-358.
https://doi.org/10.1017/S0020743800051977

[34] Al-Jahiz, Amr b. Bar al-Jahili. (1969). al-Mahasin wal-Addad. Beirut: Dar Sa'b.

[35] Ibn Manzur, Jamal al-Din Muhammad. Lisan al-'Arab. Every edition.

[36] Morel, Jean-Paul. (1993) "the Craftsman." in Andrea Giardina ed. the Romans, Lydia G. Cochrane trans. Chicago: University of Chicago Press, , p. 214-244.

[37] Shakir A. M. and Harun A. eds. (1361/1942) Al-Mufaddaliyat. Cairo.

[38] Mu'ti, Ali. (1423/2003). Tarikh al-Arab al-Iqtisadi qabl al-Islam. Beirut: Dar al-Manhal.

[39] O'Leary, De Lacy. (1927). Arabia before Muhammad. London.

[40] Oppenheim, Leo. (1977). Ancient Mesopotamia. Chicago: the University of Chicago Press.

[41] Plato. (1931). the Dialogues of Plato, B. Jowett, trans. Oxford: Oxford University Press.

[42] Qays b. al-Khatim. (1967). Diwan. Nasir al-Din al-Asad, ed. Beirut: Dar Sadir.

[43] Al-Raghib al-Asfahani, al-Husayn b. Muhammad al-Raghib alAsfahani. (n.d.) Muhadarat al-Udaba'. Beirut: Dar Maktabat alHayat.

[44] Mclughlin, Raoul. (2010). Rome and the Distant East. London: Continuum,

[45] Retsö, J. (2003). the Arabs in Antiquity. London and New York: RoutledgeCurzon.

[46] Rosen-Ayalon, Miriam. (1973). "Further considerations pertaining to Umayyad art." Israel Exploration Journal, 23, 92-100.

[47] Rosen-Ayalon, Miriam. (2005). "From Jahiliyya to Islam: an aspect of Islamic art." in JSAI, 30: 483-505.

[48] Strabo. (1854). Geography, H.S. Hamilton, trans. London: Henry G. Bohn.

[49] Taha, Rahim, H. (2015). “al-Alqab wal-Waza'if wal-Hiraf fi alKitabat al-Hadariyya." In Majallat Wasit lil-Ulum al-Insaniyya, Vol.11, no. 29: 441-464.

[50] Tanaway, Christopher. (Winter, 1992). "Arts and Crafts in Plato and Collingwood." In The Journal of Aesthetics and Art Criticism, Vol. 50, No. 1, pp. 45-54. https://doi.org/10.2307/431066

[51] Tha'alibi, Abu Mansur Abd al-Malik al-Tha'alibi. (1867) Lâ̂Á'f alMa'arif. P. de Jong, ed. Leiden, pp. 77-78.

[52] Abd al-Aziz, H. and al-Hamid, A. eds. (1999) Thalath Makhtutat Nadira fi al-Jins. Cairo: Dar al-Khayyal.

[53] Al-Tijani, Muhammad b. Ahmad al-Tijani. (1992). Tuhfat al-Arus wa-Mit'at al-Nufus. Jalil al-Atiyah, ed. London: Dar al-Rayyis Books.

[54] Tirmidhi, Abu Isa Muhammad b. Isa Tirmidhi. (1419/1999) .Sunan. Cairo: Dar al-Hadith.

[55] Torrey, Charles. (1933). the Jewish foundation of Islam. New York.

[56] al-Turki, Hind. (1432/2011). Mamlakat Qidar. Riyadh: Maktabat alMalik Fahd al-Wataniyya.

[57] Uqla, I. and Khrisat, M. (2010). "Kitab al-Mathalib lil-Haytham bin Adiy." in al-Majalla al-Urduniyya lil-Tarikh wal-Athar, Vol. 4/3,2345.

[58] Yaqut, Shihab al-Din Yaqut al-Hamawi. (1397/1977) .Mu'jam alBuldan. Beirut: Dar Sadir.

Contact email:

ghabinahmad@gmail.com 